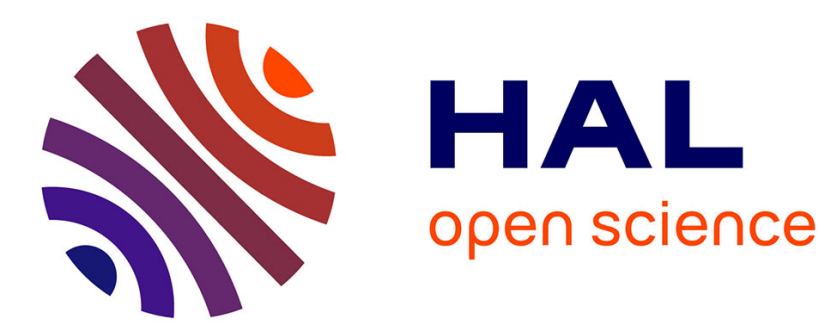

\title{
Drought and Civil War in Sub-Saharan Africa
}

Mathieu Couttenier, Raphaël Soubeyran

\section{To cite this version:}

Mathieu Couttenier, Raphaël Soubeyran. Drought and Civil War in Sub-Saharan Africa. 2011. halshs-00962481

\section{HAL Id: halshs-00962481 https://shs.hal.science/halshs-00962481}

Preprint submitted on 21 Mar 2014

HAL is a multi-disciplinary open access archive for the deposit and dissemination of scientific research documents, whether they are published or not. The documents may come from teaching and research institutions in France or abroad, or from public or private research centers.
L'archive ouverte pluridisciplinaire HAL, est destinée au dépôt et à la diffusion de documents scientifiques de niveau recherche, publiés ou non, émanant des établissements d'enseignement et de recherche français ou étrangers, des laboratoires publics ou privés. 


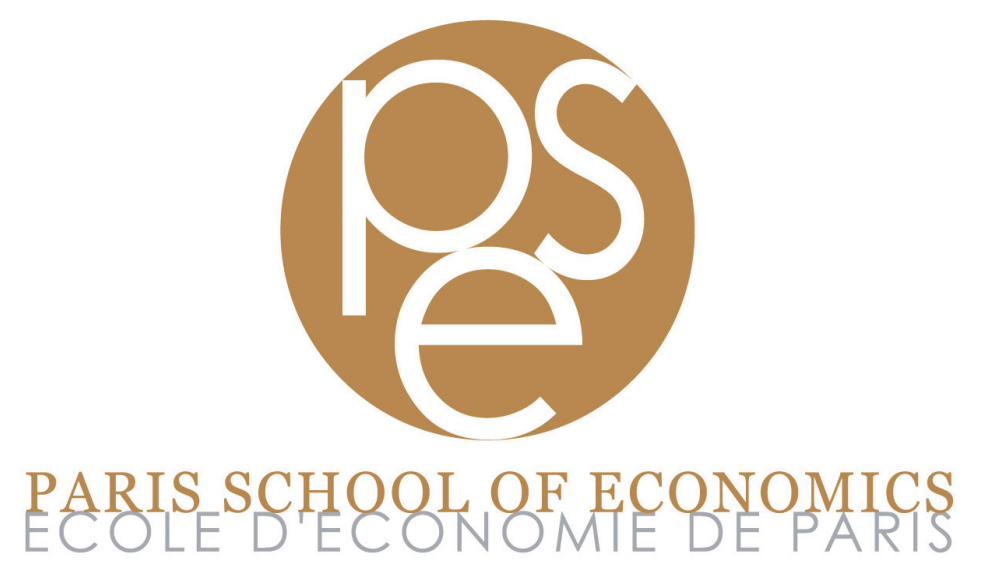

Drought and Civil War in Sub-Saharan Africa.

Mathieu COUTTENIER

Paris School of Economics and

Sciences Po
Raphaël SOUBEYRAN

INRA-LAMETA and IDEP

Montpellier

\section{G-MonD}

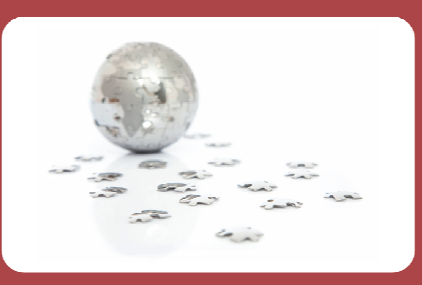

Working Paper n²1

For sustainable and inclusive world development 


\title{
Drought and Civil War in Sub-Saharan Africa *
}

\author{
Mathieu Couttenier ${ }^{\dagger} \quad$ Raphael Soubeyran ${ }^{\ddagger}$
}

This Version: July 2011, 12

\begin{abstract}
This paper contributes to the heated debate on the link between climate and civil war. We exploit a large dataset of a drought index commonly used in hydrology, the Palmer Drought Severity Index (PDSI). The PDSI is based on a hydrological model and is a cumulative measure that takes account of past climatic variables. Our analysis takes account of country fixed effects, removal of the most influential observations, use of alternative sample periods and changes to the battle-death threshold. Overall, results show a robust link between drought and civil war in Sub-Saharan African states after independence.
\end{abstract}

Keywords: Climate Change, Drought, Civil War.

JEL Codes: O10, O55, P0, Q0

*Acknowledgements: To be added later. Mathieu Couttenier acknowledges financial support from Paris School of Economics (G-MonD) and the Stanford Political Science Department for its welcome. Raphael Soubeyran acknowledges financial support from the ANR project "RISECO", ANR-08-JCJC-0074-01.

${ }^{\dagger}$ Paris School of Economics (Universite Paris 1) and Sciences Po

Mail : mathieu.couttenier@univ-paris1.fr

${ }_{\ddagger}^{\ddagger}$ INRA-LAMETA and IDEP Montpellier

2 Place Viala, 34060 Montpellier, France

Mail : soubeyra@supagro.inra.fr 


\section{Introduction}

Climate change will generate an increase in the number of abnormal climatic events, such as droughts, floods and hurricanes (Intergovernmental Panel on Climate Change, 2007). These climatic anomalies might have disastrous consequences for countries with scarce fresh water supply and economies that depends on local agriculture. Given that the poorest of African households derive between $60 \%$ and $100 \%$ of their income from agricultural activities (Davis et al., 2007) and often have no access to safe water.1] Sub-Saharan Africa is one of the most adversely climate change affected regions in the world. The civil war in Darfur is an ethnic conflict between Arabs and Black Africans, but there is a consensus that drought (and desertification) is a contributory causes of this war because it increases disputes over arable land and water (Stephan, 2009). Climate anomalies may increase competition for resources, and cause tensions that escalate into civil war. In this paper, we exploit a large dataset from the Palmer Drought Severity Index, a drought index used in hydrology, to show that drought has had a positive and robust effect on the incidence of civil war, in the period 1945-2005, in Sub-Saharan African states following independence.

Our paper contributes to recent and heated debate on the link between climate and civil war. The seminal paper by Miguel et al. (2004) refers to the Sub-Saharan African countries in the period 1981-1999 and shows that positive rainfall variations decrease the likelihood of civil war through their positive impact on GDP Burke et al. (2009) focus on the direct link between climate and civil war. They study a reduced form relationship between rainfall, temperature, and civil war and show that higher temperatures increase the likelihood of civil war. Several

\footnotetext{
${ }^{1}$ Many African people have no secure access to freshwater. Only $22 \%$ of Ethiopians, $29 \%$ of Somalis and $42 \%$ of Chadians have secure access to freshwater.

${ }_{2}$ Brückner (2010) uses a similar approach and shows that civil war is more likely to occur following an increase in population.
} 
scholars have challenged the robustness of the link between rainfall/temperature and civil war; their arguments fall into two categories.

The first set of arguments relates to the lack of robustness to changes in the data and/or in the coding choices. Jensen and Gleditsch (2009) argue that the measure of conflict in Miguel et al. (2004) is problematic and that estimates of the effect of growth on civil conflict should be limited to conflict in a state territory. Along the lines of Fearon and Laitin (2003), they consider that negative economic shocks will decrease the capacity of governments to send troops to fight in civil wars in other states; however, Burke et al. (2010a) explain this mechanism as negative economic shocks making it easier to recruit fighters (because of their reduced opportunity cost). Buhaug (2010) argues that the result is not robust to changes in the model specification (fixed effects and trends), in the rainfall and precipitation measures, or changes in the battle death threshold (which allows us distinguish between times of civil war and peace). Buhaug et al. (2010) argue that the effect is not robust to removing few very influential problematic observations, nor to alternative sample periods (within the $1960-2008$ period) $!^{3}$

The second category of critique relates to the choice to model climate. Ciccone (2011) argues that Miguel et al. (2004)'s finding rests on their choice of estimating the link between rainfall variations and civil conflict. He claims that the result is driven by a positive correlation between lagged rainfall levels and civil conflict. Ciccone (2011) uses the latest data and finds no link between rainfall levels and civil conflict. Miguel and Satyanath (2011)'s response is that if the focus is on the causal relationship between economic shocks and civil conflict, the use of rainfall levels rather than rainfall variations does not affect their initial result. They provide some theoretical arguments to explain why they think that rainfall variations are a better measure

\footnotetext{
${ }^{3}$ See also the argument in Burke et al. (2010a) and Burke et al. (2010b) on the relevance of Buhaug's criticism.
} 
than rainfall levels.

The contribution of this paper is threefold. First, we exploit a large dataset from the PDSI (Palmer, 1965), 4 The PDSI provides a better measurement of drought than precipitation or temperature levels. The PDSI is based on a hydrological model and it is a cumulative measurement which takes into account past climatic variables. Second, our database covers a longer time period (1945-2005) than the studies in the literature which usually refer to the 1980s and the 1990s. Third, we find a positive and significant effect of drought on the incidence of civil war in Sub-Saharan African states after their independence. This result is robust to changes in the model specification (fixed effects and trends), to the removal of the most influential observations, to the use of alternative sample periods and to changes in the battle death threshold.

The remainder of the paper is structured as follows. Section 2 describes the PDSI data, the control variables and our estimation framework. Section 3 presents our results regarding the effect of drought on the incidence of civil war. Section 4 concludes.

\section{Data and estimation framework}

\subsection{Palmer Drought Severity Index (PDSI)}

Measuring rainfall and temperature is not a sufficient measure of drought. For instance, the temporal distribution of rainfall along the year and the accumulation capacity of the soil also matter. Hydrologists and meteorologists do not rely on rainfall and/or temperature data alone to measure drought. The PDSI is the most prominent meteorological index of drought. It takes into account of local conditions and the local area's climate history. PDSI values for two different

\footnotetext{
${ }^{4}$ This has not been widely exploited in economics (with the exception of Landon-Lane et al. (2009) for the United States).
} 
countries with the same current temperature and rainfall levels may differ because of differences in the local conditions (e.g. day length, soil characteristics). PDSI values also varies within the same country although temperature and rainfall levels may be the same (at two different dates) because the climate history is different.

The PDSI measures moisture differences from a climatological normal. It is based on a supply and demand model of soil moisture and is calculated on precipitation and temperature data as well as the local Available Water Content (AWC) of the soil. All the basic terms in the water balance equation can be determined, including evapo-transpiration, soil recharge, runoff, and moisture loss from the surface layer. The PDSI is a weighted cumulative sum of monthly terms measured as differences from the monthly average, over the $1870-2005$ period. This index captures departures from average local climatic conditions.

PDSI data are a world time series available for 1870-2005, geolocalised and available at a resolution of 2.5 degrees by 2.5 degrees. We use the scale [0,30] for the PDSI values: a value of 15 refers to the "normal" climatic situation. As defined by Palmer, a PDSI value above 25, indicates an "extremely dry" climate, while a PDSI value below 5 is an "extremely wet" climate. To carry out our country-year level analysis, we aggregate the monthly geolocalised PDSI data to compute the country-year average. The distribution of this variable for the Sub-Saharan region for the period $1945-2005$ is normal $5^{5}$ the average value is 15.376 , which is close to the normal climatic situation and the standard deviation is 2.52 , which is $16.4 \%$ of the average. Figure 1 shows the density of the PDSI for the Sub-Saharan region for the period 1945-2005 and its evolution over the decades. The density curve moves to the right, i.e. the Sub-Saharan climate has became dryer. The curve becomes flatter and more right skewed. In other words,

\footnotetext{
${ }^{5}$ According to the Chi square test.
} 
more and more countries' climates are approaching "extreme dryness".

Figure 1: PDSI Density
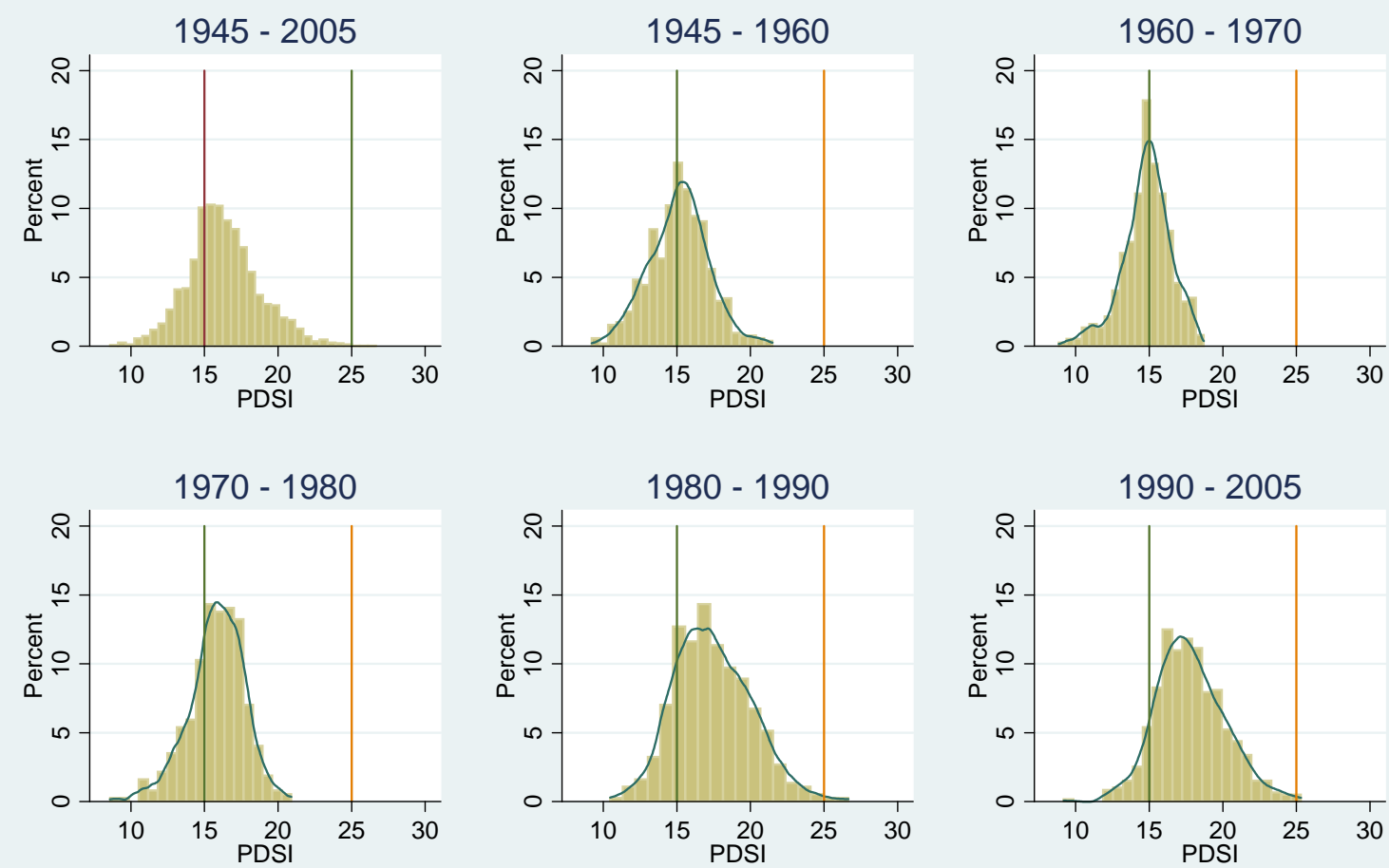

Drought density (kernel) by decades for Sub-Saharan Africa

\subsection{Other Variables}

We use the last version of the UCDP/PRIO civil war database (version 4-2009). We use the dummy variable civil war incidence, which is equal to 1 for years with a number of deaths greater than 1,000, and 0 otherwise (we discuss our results for alternative coding choices later). The UCDP/PRIO database includes three categories of conflict: extrasystemic, internal and internationalised armed conflict. These are defined as follows. An extrasystemic armed conflict occurs between a state and a non-state group outside its own territory. Extrasystemic wars include colonial wars and imperial wars. An internal armed conflict occurs between the government of a state and one or more internal opposition group(s) without intervention from other states. An internationalised internal armed conflict occurs between the government of a state 
and one or more internal opposition group(s) with intervention from other states. We use data from the Correlates Of War (COW) to check the robustness of our results.

We also consider other determinants found in the literature (Fearon and Laitin, 2003; Collier and Hoeffler, 2004). GDP growth and Population data are from the World Bank. The Percentage of Mountainous Terrain, Oil, U.K. and French colony are from Fearon and Laitin (2003). Oil is a dummy that is 1 if a country's fuel exports exceeds one-third of its export revenues. Polity 2 are from the Polity IV project; its scale is the unit interval with the higher values indicating stronger democratic institutions. U.K. Colony and French Colony are two time invariant dummies for U.K. and French colonies.

\subsection{Estimation Framework}

The recent debate on the existence of a link between climate and civil war in Sub-Saharan Africa uses country fixed effects and time trends. They serve as substitutes for variables suspected to be endogenous (e.g. GDP), to control for unobserved heterogeneity, and to take account of temporal trends in the causes of conflicts. In most of our estimates, we follow the literature and use a reduced-form relationship which links civil war and drought:

$$
\text { War }_{i t}=\beta_{0}+\beta_{1} \text { Drought }_{i t}+\text { Trends }_{i t}+\alpha_{i}+\epsilon_{i t},
$$

where $i$ denotes the country and $t$ denotes time. $W a r_{i t}$ is the incidence of civil war or onset of the civil war. The civil war onset index is coded 1 for the first year of the civil war, 0 for each year of peace and set to missing from the second year to the last year of the civil war. The incidence of civil war index, which is a subsume of civil war outbreak and civil war 
continuation, is a dummy variable which is 1 for years with a number of battle related deaths greater than 1,000 and 0 otherwise (peace).

Drought $_{i t}$ is the PDSI and $\epsilon_{i t}$ is the error term. Most of our specifications include country fixed effects $\left(\alpha_{i}\right)$ and country specific time trends (Trends $\left.s_{i t}\right)$. The probit and logit procedures exclude countries that have not experienced a civil war when country fixed effects are included and this restricts our sample to 13 countries. Our database includes 37 countries (see Table 6 in Appendix A) and we apply the least squares method to most of our estimates to retain the maximum number of observations. All reported standard errors are consistent for heteroskedasticity.

It is highly probable that least squares estimates of the error terms in equation 1 will present time-series correlation within country observations. Bertrand et al. (2004) highlight that the inclusion of country fixed effects is not enough to overcome this issue. The usual method is to compute cluster-robust standard errors at country level as in Ciccone(2011). Ignoring clustering leads to underestimation of the standard errors. However, in our case clustering introduces another issue because our specification includes a larger number of exogenous variables (37 country dummies (fixed effects), 37 country specific time trends and the PDSI) than the number of clusters (37). Cameron and Miller (2011) claim that it is not possible to perform a test of overall significance of the regression when the number of exogenous variables is at least as high as the number of clusters ${ }^{6}$ This issue is as important as the issue of the bias induced by ignoring clustering at country level. Therefore, when estimating cluster-robust standard errors we do not include fixed effects and country specific time trends in the specification.

\footnotetext{
${ }^{6}$ It is not possible to test for overall significance of the regression if the rank of the cluster-robust estimate of the variance-covariance matrix of the least squares estimator is not less than the number of clusters.
} 


\section{Drought and Civil War Robustly Linked in Independent}

\section{Countries}

\subsection{Main results}

We focus on the effect of drought on the incidence of civil war over the period 1945 to 2005 . The first column in Table 1 shows our estimates of equation (1) without country fixed effects and trends. The dependent variable includes extrasystemic, internal and internationalised armed conflict (as defined in the UCDP/PRIO civil war database). Drought and the civil war incidence index are positively and significantly correlated, i.e. civil war occurs when and where the climate is dry during the 1945-2005 period. This result contrasts with the results in the litterature obtained using rainfall and temperature data. Indeed, Buhaug (2010) finds no significant correlation between temperature/rainfall and the incidence of civil war in the period 1981-2002 (the sensitivity of our result to the time window is discussed in section 3.2). As Buhaug (2010) argues, the exogenous nature of the climate index and our conscious focus on the relatively homogenous Sub-Saharan Africa, might lead us to assume that the simple correlation is sufficient. However, if there is a correlation this may be a statistical artefact and there may be no causal link between drought and civil war due to omission of the variables representing the true underlying forces. To overcome the potential bias induced by omission of independent variables, we introduce country dummies and country specific time trends (column (2) in Table 1). The positive link between drought and the incidence of civil war during 1945-2005 is no longer significant.

The previous regressions were run for data including extrasystemic, internal and internationalised civil wars. We think that the non-significant effect shown in column (2) in Table 1 
may be due to the inclusion of extrasystemic civil war. Jensen and Gleditsch (2009) point out that countries involved in civil wars in other states should not be included in the analysis.7 They argue that according to Fearon and Laitin (2003), negative economic shocks should decrease the capacity of governments to send troops to civil wars in other states. We think that this restriction should be considered in the context of our analysis; thus, we run a third regression using the specification in (1) with country fixed effects and trends. Column (3) presents our estimates when extrasystemic civil wars are excluded. The results suggest that drought has no causal effect on the incidence of civil war since the coefficient of the PDSI variable is not significant.

Table 1: Drought and Civil War Incidence: 1945 -2005

\begin{tabular}{l|ccc}
\hline $\begin{array}{l}\text { Specifications } \\
\text { War (PRIO) }\end{array}$ & $\begin{array}{c}(1) \\
\text { All }\end{array}$ & $\begin{array}{c}(2) \\
\text { All }\end{array}$ & $\begin{array}{c}(3) \\
\text { Internal \& } \\
\text { Internationalized }\end{array}$ \\
\hline Drought (PDSI) & $\begin{array}{c}0.422^{* *} \\
(0.186)\end{array}$ & $\begin{array}{c}0.301 \\
(0.201)\end{array}$ & $\begin{array}{c}0.230 \\
(0.189)\end{array}$ \\
& No & Yes & Yes \\
$\begin{array}{l}\text { Country Fixed Effect: } \\
\text { Country Specific } \\
\text { Time Trends : }\end{array}$ & No & Yes & Yes \\
& & & 2,257 \\
\hline $\begin{array}{l}\text { Observations } \\
\text { R-squared }\end{array}$ & 2,257 & 2,257 \\
\hline \hline
\end{tabular}

However, these results are not sufficient to exclude the possibility of a causal link between drought and civil war in Sub-Saharan Africa. The history of Sub-Saharan Africa reveals that there were important political changes throughout the $20^{\text {th }}$ century. Many African countries were colonized before World War II and decolonized after World War II. The process of decolonization and emergence of new states presents a theoretical and empirical challenge. It raises

\footnotetext{
${ }^{7}$ They show that the estimated effect of economic growth on civil war is reduced compared to Miguel et al. (2004)'s.
} 
questions about the inclusion or exclusion of anticolonial civil wars in the analysis (Fearon and Laitin, 2003). Fearon and Laitin (2003) propose two ways to include anticolonial civil wars. The first corresponds to the way the data we used in our estimates shown in Table 1 are coded. The data are coded such that Ivory Coast is a single "state" for the whole 1945-2005 period (in fact it was part of the French empire from 1895 to independence in 1960). In other words, we consider "states" that did not exist (such as "Ivory Coast" from 1945 to 1960). This coding strategy also ignores the existence of colonial empires, but note that this is a potential reason for the non significant effect of the estimates in columns 2 and 3 in Table 1 . Indeed, the significance of drought may be strongly reduced because a coloniser may compensate for its adverse effects. The second strategy is to consider colonial empires. For instance, Ivory Coast and Cameroon are categorized as belonging to the French empire before they gained independence (in 1960). Considering colonial empires requires the construction of explanatory variables for whole empires. Fearon and Latin conclude that, although possible, it would be very problematic to code variables such as GDP, ethnic fractionalization and democracy score. Also, in our context it makes little sense to assign a climate value to a whole colonial empire. For instance, it would be meaningless to assign the PDSI value of the French metropole (coloniser) to French colonies (such as Ivory Coast and Cameroon), or to assign the value of the PDSI averaged over the whole French empire to French colonies.

We choose then to focus on civil wars in independent African states and to exclude the colonial period. The time frame we consider is the period from a country's independence to the most recent year in our data, 2005. For example, the time frame for Ghana starts in 1957, Mozambique and Angola in 1975, and the former French colonies in 1960. Table 2 shows the estimates of the specification in equation (1) restricting the sample to independent countries. Column (1) 
in Table 2 shows the estimates with the dependant variable that includes both internationalised and internal civil wars (country fixed effects and country time trends are included) ${ }^{8}$ The effect of drought on civil war is positive and significant.

We can distinguish between internationalised civil wars and internal civil wars because they are different (in internationalised civil wars the underlying cause of the continuation of war may depend on the intervener). We find that drought has no effect on the incidence of internationalised civil wars (column (2) in Table 2). We suspect that there is no effect because we do not control for the characteristics of the intervener. However, we do not pursue this direction since analysis of interventions is outside the scope of the present paper. We choose instead to focus on internal civil wars.

We find that drought (PDSI) has a positive effect on the incidence of internal civil wars. Column (3) in Table 2 represents our preferred specification (124 observations with War $\left._{i t}=1\right)$. In columns (4) and (5) we add the lagged civil war incidence variable as the probability that civil war depends on whether there was a war in the previous year. Column (4) reports least squares estimates and column (5) reports system-General Method of Moment (GMM) estimates of this dynamic equation. 9 As the Sub-Saharan countries have some common trends, such as economic development and democratization, we include a common time trend (across countries). The effect of drought is still positive and significant (see column (6) in Table 2). Thus, the results in Table 2 show a robust effect of drought on civil war in the Sub-Saharan countries after independence.

\footnotetext{
${ }^{8}$ Includes 128 observations of civil war.

${ }^{9}$ The least squares estimator is inconsistent for a finite time-series dimension; the system-GMM is consistent as the cross-sectional dimension goes toward infinity even when the number of years is finite, see Wooldridge (2002), page 304 or Greene (2002), page 308.
} 
Table 2: Drought and Civil War Incidence: After independence

\begin{tabular}{|c|c|c|c|c|c|c|}
\hline $\begin{array}{l}\text { Specifications } \\
\text { War }\end{array}$ & $\begin{array}{c}(1) \\
\text { Internal \& } \\
\text { Internationalized }\end{array}$ & $\begin{array}{c}(2) \\
\text { Internationalized }\end{array}$ & $\begin{array}{c}(3) \\
\text { Internal }\end{array}$ & $\begin{array}{c}(4) \\
\text { Internal }\end{array}$ & $\begin{array}{c}(5) \\
\text { Internal }\end{array}$ & $\begin{array}{c}(6) \\
\text { Internal }\end{array}$ \\
\hline $\begin{array}{l}\text { Drought (PDSI) } \\
\text { Lag Incidence }\end{array}$ & $\begin{array}{c}0.719 * * * \\
(0.264)\end{array}$ & $\begin{array}{l}-0.0328 \\
(0.138)\end{array}$ & $\begin{array}{c}0.669 * * * \\
(0.246)\end{array}$ & $\begin{array}{c}0.352^{*} \\
(0.188) \\
0.560^{* * *} \\
(0.0584)\end{array}$ & $\begin{array}{c}0.460^{*} \\
(0.254) \\
0.568 * * * \\
(0.0216)\end{array}$ & $\begin{array}{l}0.371^{*} \\
(0.223)\end{array}$ \\
\hline $\begin{array}{l}\text { Country Fixed Effect: } \\
\text { Country Time } \\
\text { Trends : }\end{array}$ & Yes & Yes & Yes & Yes & Yes & Yes \\
\hline Common Time Trends: & - & - & - & - & - & Yes \\
\hline $\begin{array}{l}\text { Observations } \\
\text { R-squared }\end{array}$ & $\begin{array}{l}1,597 \\
0.445\end{array}$ & $\begin{array}{l}1,597 \\
0.433\end{array}$ & $\begin{array}{l}1,597 \\
0.321\end{array}$ & $\begin{array}{l}1,594 \\
0.533\end{array}$ & $\begin{array}{c}1,594 \\
-\end{array}$ & $\begin{array}{l}1,597 \\
0.278\end{array}$ \\
\hline
\end{tabular}

Note: Robust Standard errors in parentheses with ${ }^{* * *},{ }^{* *}$ and ${ }^{*}$ respectively denoting significance at the $1 \%, 5 \%$ and $10 \%$ levels. Column (1) to (4) and (6) using OLS. The method of estimation is system-GMM for column (5).

\subsection{Robustness checks}

In this section, we show that our results are robust and pass several sensitivity tests. One of the arguments used against the result in Miguel et al. (2004)'s seminal work is that the link between rainfall and civil war fails to pass several sensitivity tests (see Buhaug (2010)). We show that our results are much less sensitive.

First, we test the sensitivity of our results to a change in the time frame of the sample considered. The processes of democratization and the development of Sub-Saharan Africa might have induced changes in the relationship between drought and civil war during the post-World War II period. Thus, the effect of drought on civil war may be sensitive to the time frame in our sample. We use our preferred specification (in column (3) in Table 2) and re-estimate the effect of drought on civil war for all possible time intervals of a minimum of 20 consecutive years (i.e. 861 estimates). The graph at the top of Figure 2 represents the size of the coefficient of the 
PDSI $\left(\widehat{\beta}_{1}\right)$ for every possible start and end years in the timescale. We choose the value of the estimated coefficient of the PDSI in our preferred specification (0.67) as a reference (column (3) in Table 2). The values are classified into three sets: the first contains negative values (pale grey), the second contains values between 0 and 0.67 (grey) and the third contains values above 0.67 (dark). In most cases, the value of the estimated coefficient of the PDSI is larger than 0.67. The graph at the bottom of Figure 2 represents the degree of significance of the estimated coefficient of the PDSI (whether significant at the $10 \%$ level of confidence or not). The coefficient of drought is almost always positive, significant, and higher than 0.67 when the timescale considered ends after the beginning of the 1980s and is smaller and non significant when the timescale ends earlier. This result may be due to the small number of ongoing civil wars before the 1980 (28 observations with $W a r_{i t}=1$ ) and by the frequency of "normal" climatic situations (see Figure 11. Our result is very robust to a change in the time frame, compared to estimates that use rainfall and temperature data (see the discussion of Buhaug et al. (2010) on Burke et al. (2010a)).

We test the robustness of our result to the exclusion of the most influential observations 10 Our preferred estimates (column (3) in Table 2) run over 1,597 observations, 124 of which are observations with civil war. Thus, the results may be very sensitive to the inclusion/exclusion of a small number of observations. We use the dfbeta statistic for the PDSI to identify observations that are likely to exercise an overly large influence. We use our preferred specification (column (3) in Table 2). The critical value is $2 / \sqrt{n}$, where $n$ is the number of observations. We find a threshold that amounts to .05 and identify 74 observations with higher dfbeta values. When these observations are excluded, the estimated coefficient of the PDSI is lower and less

\footnotetext{
${ }_{10}$ Buhaug et al. (2010) argue that the estimates in Burke et al. (2010a) regarding temperature data do not pass this test.
} 
Figure 2: Drought Effect with Different Time Frame

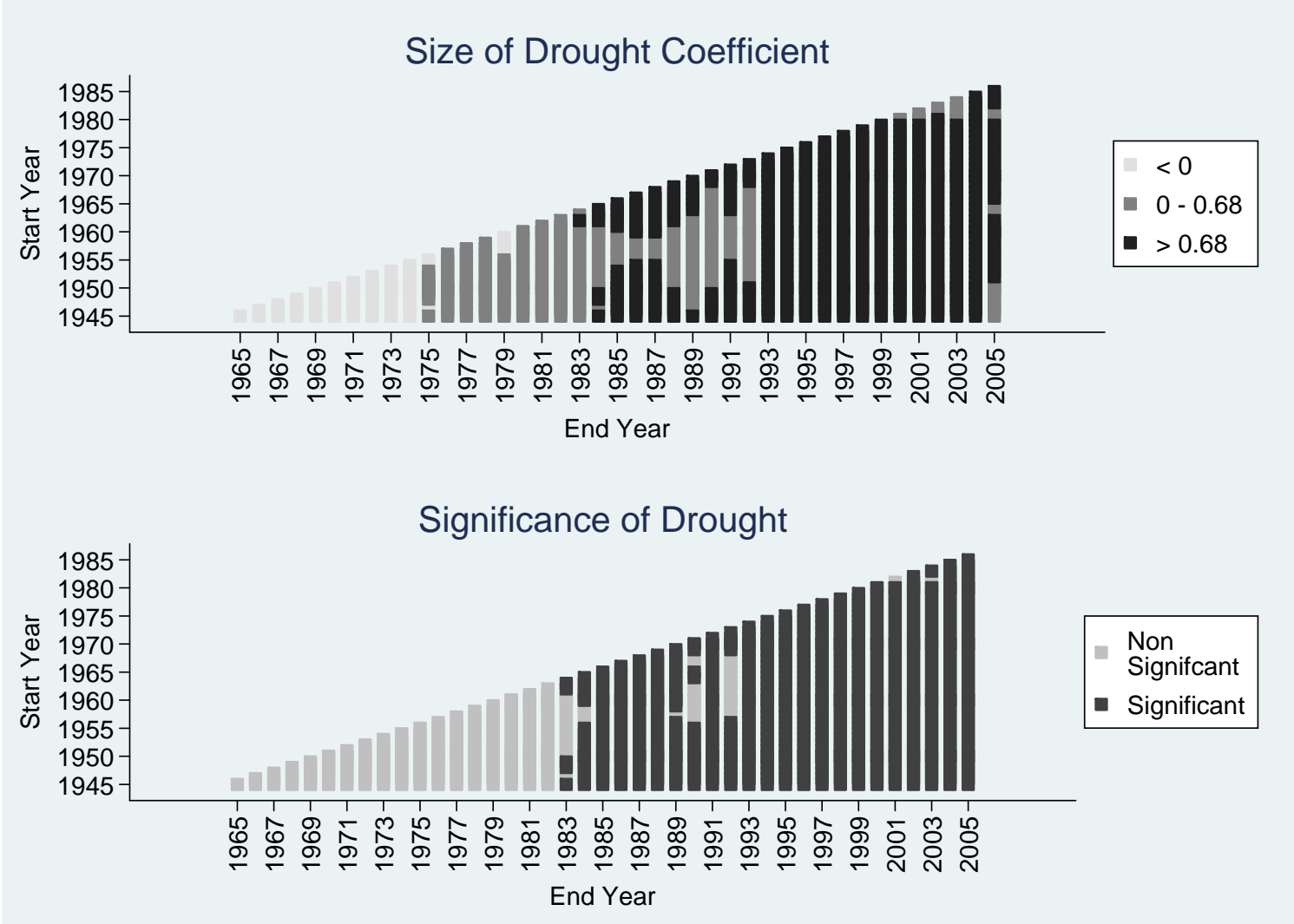

significant; however, it remains significant at the $10 \%$ level. This confirms the robustness of the effect of drought for the post colonial period (see Table 5 in Appendix A).

We now test whether our results are sensitive to a change in the battle-related deaths threshold. There is an usual distinction in the litterature, between civil war and civil conflict, according to the number of battle-related deaths (the focus in this paper is on civil war years, e.g. when the number of battle related deaths per year is larger than 1,000). We re-code our dependent variable $W a r_{i t}$ for each threshold between 25 and 200,000 battle-related deaths per year and re-estimate our preferred specification. Figure 3 reports the value of the estimated coefficient of the PDSI at the $10 \%$ confidence interval (grey area). The coefficient of the PDSI is positive and significant as long as the threshold is higher than 1000 deaths. ${ }^{11}$ The coefficient of the PDSI is

\footnotetext{
${ }^{11}$ It becomes non-significant for thresholds higher than 50,000 deaths per year, but considers only 2 observations of civil war.
} 
positive for thresholds between 25 and 999 (battle deaths each year), but not significant in most cases. Drought has a positive and robust effect on civil war as long as the battle-death threshold is at least 1,000 .

Figure 3: Drought Effect and Intensity

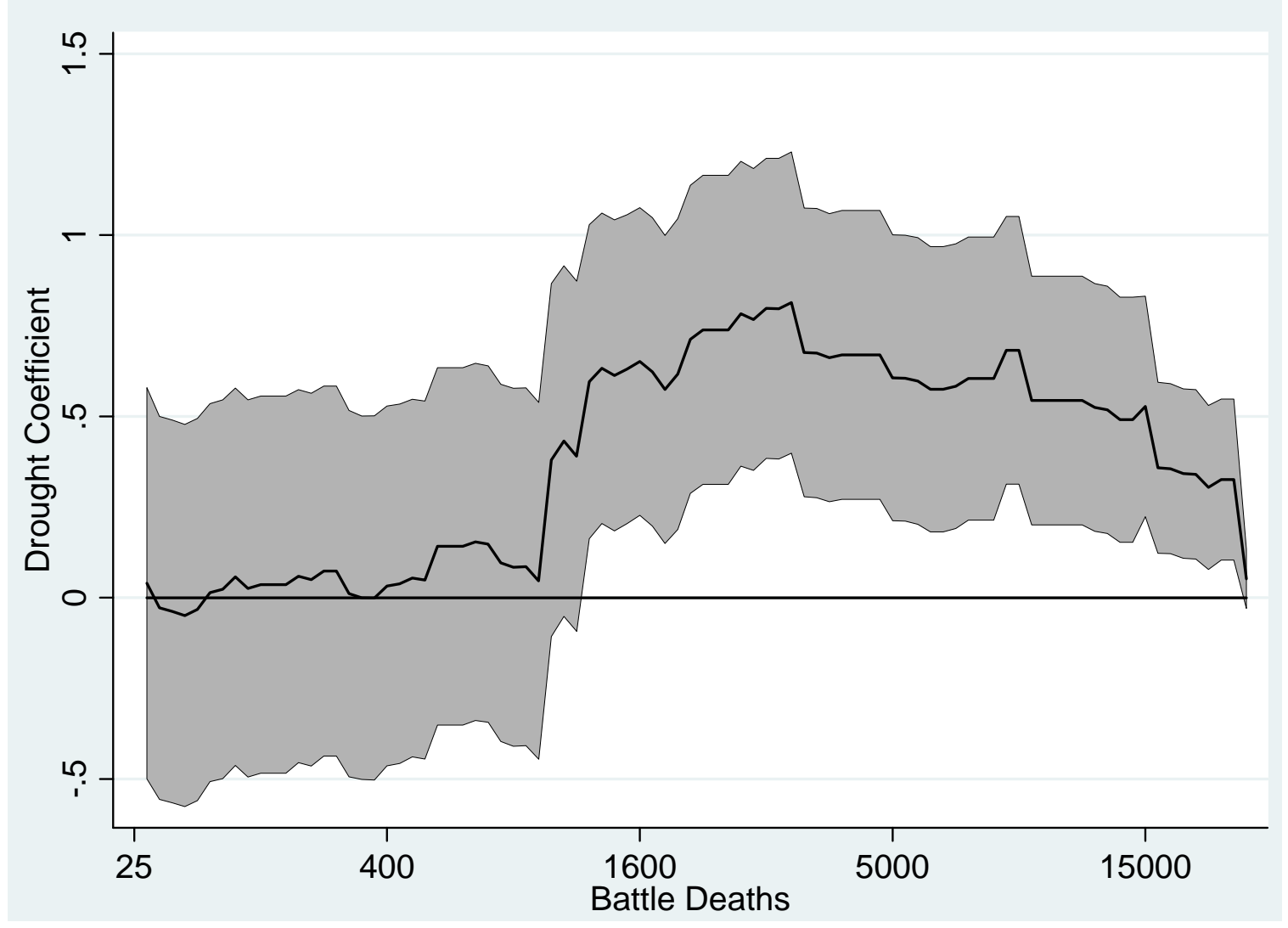

Another usual index of civil war is onset (or outbreak) of civil war. It is set at 1 for the first year of civil war, set to missing for the subsequent civil war years, and at 0 for peace years. Table 3 presents our results. The four columns correspond to the specifications used to find the estimates in Table 1 column (3) and Table 2, columns (1)-(2) and (3) (respectively) where the index of civil war incidence is replaced by the onset of civil war index. Our results are qualitatively unaffected.

We test also for whether exploiting the Correlates Of War (COW) database rather than the UCDP/PRIO database affects our results. We find our results hold if we estimate our preferred 
Table 3: Drought and Civil War Onset

\begin{tabular}{|c|c|c|c|c|}
\hline $\begin{array}{l}\text { War (PRIO) } \\
\text { Time Sample }\end{array}$ & $\begin{array}{c}(1) \\
\text { Internal \& } \\
\text { Internationalized } \\
1945-2005\end{array}$ & $\begin{array}{c}(2) \\
\text { Internal \& } \\
\text { Internationalized } \\
\text { After Inde. }\end{array}$ & $\begin{array}{c}\text { (3) } \\
\text { Internationalized } \\
\text { After Inde. }\end{array}$ & $\begin{array}{c}\text { (4) } \\
\text { Internal } \\
\text { After Inde. }\end{array}$ \\
\hline Drought (PDSI) & $\begin{array}{c}0.125 \\
(0.107)\end{array}$ & $\begin{array}{c}0.330 * * \\
(0.151)\end{array}$ & $\begin{array}{c}-0.00224 \\
(0.100)\end{array}$ & $\begin{array}{l}0.236 * \\
(0.141)\end{array}$ \\
\hline $\begin{array}{l}\text { Country Fixed Effect: } \\
\text { Country Time } \\
\text { Trends : }\end{array}$ & $\begin{array}{l}\text { Yes } \\
\text { Yes }\end{array}$ & $\begin{array}{l}\text { Yes } \\
\text { Yes }\end{array}$ & $\begin{array}{l}\text { Yes } \\
\text { Yes }\end{array}$ & $\begin{array}{l}\text { Yes } \\
\text { Yes }\end{array}$ \\
\hline $\begin{array}{l}\text { Observations } \\
\text { R-squared }\end{array}$ & $\begin{array}{l}2,157 \\
0.085\end{array}$ & $\begin{array}{l}1,500 \\
0.131\end{array}$ & $\begin{array}{l}1,573 \\
0.094\end{array}$ & $\begin{array}{l}1,532 \\
0.103\end{array}$ \\
\hline
\end{tabular}

specification and that is robust to a change in the timescale (see Table 7 and Figure 6 in Appendix B).

So far, we have included country fixed effects and trends in our estimates, but not any other control variables. This prudent strategy gives us confidence that our estimates do not suffer from any endogeneity bias. However, country fixed effects and trends cannot control for all the underlying causes of civil war. Table 4 shows the results when variables that are commonlyused in the political science litterature are included (Collier and Hoeffler, 2004, Fearon and Laitin, 2003). The estimates are for the 1960-2005 period only, because of the availability of some of the variables. However this time range is still longer than the time ranges in the previous studies (usually in the range 1980-2000). Column (1) presents the estimates when we include growth of GDP, population size (log of), number of peace years, democracy index (Polity 2) and the squared democracy index (which captures non linear effects). Column (2) presents our estimates including the incidence of civil war in the previous year, instead of peace years. Column (3) estimates include common time trends instead of individual time trends, 
and column (4) estimates with country fixed effects replaced by several country-specific timeinvariant controls (surface of mountainous terrain (log \%), a dummy for U.K. colony, a dummy for French colony and a dummy for major oil exporter). Column (5) presents the results with bootstrap, cluster-robust, standard errors at country level (Cameron et al., 2008). The results are robust. Column (6) shows our estimates using a probit estimation procedure. To avoid perfect prediction, we do not include country fixed effects and trends, hence we exclude countries with no variations in the incidence of civil war index. The link between drought and civil war is still significant.

\subsection{Quantifications at country level}

In order to get some insight into the possible consequences of future droughts, we quantify the effect of drought on the probability of civil war at country level. We simulate the effect of drought, keeping all else constant and quantify changes in the distribution of the probabilities of civil war incidence for the Sub-Saharan African countries, using different scenarios. The probabilities are computed after a probit estimation using the same specification as the one in column (6) of Table 4. Typically, we consider variations to the probability of civil war incidence in 2005 as a hypothetical change in the climate from a "normal" (PDSI=15) to an "extremely dry" situation (PDSI=25). The induced variation of the average probability of civil war incidence in Sub-Saharan Africa is large: this change from a "normal" to an "extremely dry" climate increases the average probability of civil war incidence by approximately $60 \%$. This probability is $7,5 \%$ for a "normal" climate and $12 \%$ for an "extremely dry" climate. The analysis is conducted at country level. We simulate three different probabilities of civil war for each country. First, we compute the predicted probability of civil war for each country in 2005 
Table 4: Drought and Civil War Incidence with controls: After independence

\begin{tabular}{|c|c|c|c|c|c|c|}
\hline $\begin{array}{l}\text { Specification } \\
\text { War (PRIO) } \\
\text { Methodology }\end{array}$ & $\begin{array}{c}\text { (1) } \\
\text { Internal } \\
\text { OLS }\end{array}$ & $\begin{array}{c}\text { (2) } \\
\text { Internal } \\
\text { OLS }\end{array}$ & $\begin{array}{c}\text { (3) } \\
\text { Internal } \\
\text { OLS }\end{array}$ & $\begin{array}{c}\text { (4) } \\
\text { Internal } \\
\text { OLS }\end{array}$ & $\begin{array}{c}5) \\
\text { Internal } \\
\text { OLS - Cluster }\end{array}$ & $\begin{array}{c}(6) \\
\text { Internal } \\
\text { Probit }\end{array}$ \\
\hline Drought (PDSI) & $\begin{array}{l}0.714 * * * \\
(0.256)\end{array}$ & $\begin{array}{l}0.369^{*} \\
(0.220)\end{array}$ & $\begin{array}{c}0.621 * * * \\
(0.231)\end{array}$ & $\begin{array}{c}0.800 * * * \\
(0.256)\end{array}$ & $\begin{array}{l}0.849^{*} \\
(0.517)\end{array}$ & $\begin{array}{l}7.523^{*} \\
(3.968)\end{array}$ \\
\hline Growth & $\begin{array}{l}-0.0181 \\
(0.0381)\end{array}$ & $\begin{array}{l}-0.0231 \\
(0.0321)\end{array}$ & $\begin{array}{l}-0.0292 \\
(0.0385)\end{array}$ & $\begin{array}{l}-0.0175 \\
(0.0397)\end{array}$ & $\begin{array}{l}-0.0111 \\
(0.0459)\end{array}$ & $\begin{array}{l}-0.408 \\
(0.415)\end{array}$ \\
\hline Log Population & $\begin{array}{c}-0.284 * * \\
(0.122)\end{array}$ & $\begin{array}{l}-0.111 \\
(0.120)\end{array}$ & $\begin{array}{l}-0.0570 \\
(0.0704)\end{array}$ & $\begin{array}{c}0.0514 * * * \\
(0.0116)\end{array}$ & $\begin{array}{c}0.0220 \\
(0.0151)\end{array}$ & $\begin{array}{l}0.201 * * \\
(0.0849)\end{array}$ \\
\hline Peace Years & $\begin{array}{c}-0.00160 * * * \\
(0.000344)\end{array}$ & & $\begin{array}{c}-0.00195^{* * *} \\
(0.000329)\end{array}$ & $\begin{array}{c}-0.00215 * * * \\
(0.000341)\end{array}$ & $\begin{array}{c}-0.00346^{* * *} \\
(0.00124)\end{array}$ & $\begin{array}{l}-0.212 * * \\
(0.0932)\end{array}$ \\
\hline Polity 2 & $\begin{array}{c}0.318^{* *} \\
(0.135)\end{array}$ & $\begin{array}{c}0.102 \\
(0.116)\end{array}$ & $\begin{array}{c}0.167^{*} \\
(0.0919)\end{array}$ & $\begin{array}{c}0.159 \\
(0.106)\end{array}$ & $\begin{array}{c}-0.0454 \\
(0.173)\end{array}$ & $\begin{array}{l}-0.605 \\
(1.440)\end{array}$ \\
\hline Polity 2 sq. & $\begin{array}{c}-0.321 * * \\
(0.143)\end{array}$ & $\begin{array}{l}-0.111 \\
(0.120)\end{array}$ & $\begin{array}{l}-0.222 * * \\
(0.0931)\end{array}$ & $\begin{array}{l}-0.159 \\
(0.116)\end{array}$ & $\begin{array}{l}-3.32 \mathrm{e}-05 \\
(0.184)\end{array}$ & $\begin{array}{c}0.358 \\
(1.656)\end{array}$ \\
\hline Mountainous Terrain & & & & $\begin{array}{l}-0.00243 \\
(0.00675)\end{array}$ & $\begin{array}{l}0.00904 \\
(0.0121)\end{array}$ & $\begin{array}{c}0.106 \\
(0.0705)\end{array}$ \\
\hline U.k Colony & & & & $\begin{array}{l}-0.113 * * \\
(0.0563)\end{array}$ & $\begin{array}{l}-0.0478 \\
(0.0652)\end{array}$ & $\begin{array}{c}0.358 * * \\
(0.175)\end{array}$ \\
\hline French Colony & & & & $\begin{array}{c}-0.126 * * * \\
(0.0489)\end{array}$ & $\begin{array}{c}-0.124 * * * \\
(0.0478)\end{array}$ & $\begin{array}{c}-1.177 * * * \\
(0.337)\end{array}$ \\
\hline Oil & & & & $\begin{array}{c}0.0263 \\
(0.0335)\end{array}$ & $\begin{array}{l}-0.0154 \\
(0.0470)\end{array}$ & $\begin{array}{c}0.00810 \\
(0.229)\end{array}$ \\
\hline Lag Incidence & & $\begin{array}{c}0.572 * * * \\
(0.0571)\end{array}$ & & & & \\
\hline $\begin{array}{l}\text { Country Fixed Effect: } \\
\text { Country Time }\end{array}$ & Yes & Yes & Yes & - & - & - \\
\hline Trends : & Yes & Yes & - & Yes & - & - \\
\hline Common Time Trends: & - & - & Yes & - & - & - \\
\hline Observations & 1,497 & 1,480 & 1,497 & 1,448 & 1,448 & 1,448 \\
\hline R-squared & 0.362 & 0.651 & 0.326 & 0.316 & 0.162 & \\
\hline
\end{tabular}

given its individual PDSI value. Second, we compute the hypothetical probability of incidence if PDSI is equal to 15 (a "normal" climate) and 25 (an "extremely dry" climate). The three predicted probabilities for each country are reported in Table 6 . Figure 4 shows the distribution of Sub-Saharan African countries for each of the three predictions (see Appendix A). With a "normal" climatic situation $(\mathrm{PDSI}=15)$ the probability of civil war is lower than $50 \%$ for all countries except Angola (61,4\%) and Nigeria (58,3\%). Under the conditions of an "extremely dry" climate (PDSI=25), the distribution of countries becomes flatter with a shift to the right, 
and a hole appears around 50\%. Five countries (Angola, Ethiopia, Nigeria, Sudan, Uganda) have a very high estimated probability of civil war (higher than 55\%) for an "extremely dry" climate ${ }^{12}$ Although these countries have a high probability of civil war under "normal" climate conditions (PDSI=15), this increases by more than $30 \%$ with the change to an "extremely dry" climate (PDSI=25). Figure 5 presents the probabilities for the nine countries with the highest estimated probabilities of civil war, for the three scenarios (see Appendix A).

These quantifications should be interpreted with some caution since we consider only changes to drought conditions; any changes in the other variables are left aside. However, our results show clearly that drought has a strong positive effect on the risk of civil war.

\section{Conclusion}

In this paper, we used a hydrological measurement of drought, the Palmer Drought Severity Index, with values computed according to a supply and demand model of soil moisture. We showed that drought (PDSI values) and the incidence of civil war are robustly and positively linked for the independent Sub-Saharan African countries. It is important to note that, as discussed, our analysis is not subject to the criticisms leveled at studies that rely on rainfall and temperature data, and we show that our results pass several sensitivity tests.

\footnotetext{
${ }^{12}$ Uganda and Sudan were experiencing civil war in 2004, but Angola and Ethiopia were not. However, there was a civil war in Angola from 1975 to 1995 and from 1998 to 2002, and Liberia had one year of civil war in 2003. Ethiopia experienced civil war from 1975 to 1985 and from 1987 to 1991.
} 


\section{Appendix A: Figures and Tables}

Table 5: Drought and Civil War Incidence: Influential Observations

\begin{tabular}{l|cc}
\hline \hline & $(1)$ & $(2)$ \\
Sample & All Countries & w/o infl. obs. \\
\hline \multirow{3}{*}{ Drought (PDSI) } & $0.719 * * *$ & $0.161^{*}$ \\
& $(0.264)$ & $(0.0839)$ \\
& & 1,523 \\
\hline Observations & 1,597 & 0.600 \\
R-squared & 0.445 & 50 \\
Nb. Incidence & 124 & \\
\hline \hline
\end{tabular}

Note: Robust Standard errors in parentheses with ${ }^{* * *},{ }^{* *}$ and ${ }^{*}$ respectively denoting significance at the $1 \%, 5 \%$ and $10 \%$ levels.

OLS regressions for countries after independence.

Influential observations selected thanks to dfbeta statistics.

Figure 4: Estimated Distribution for the year 2005
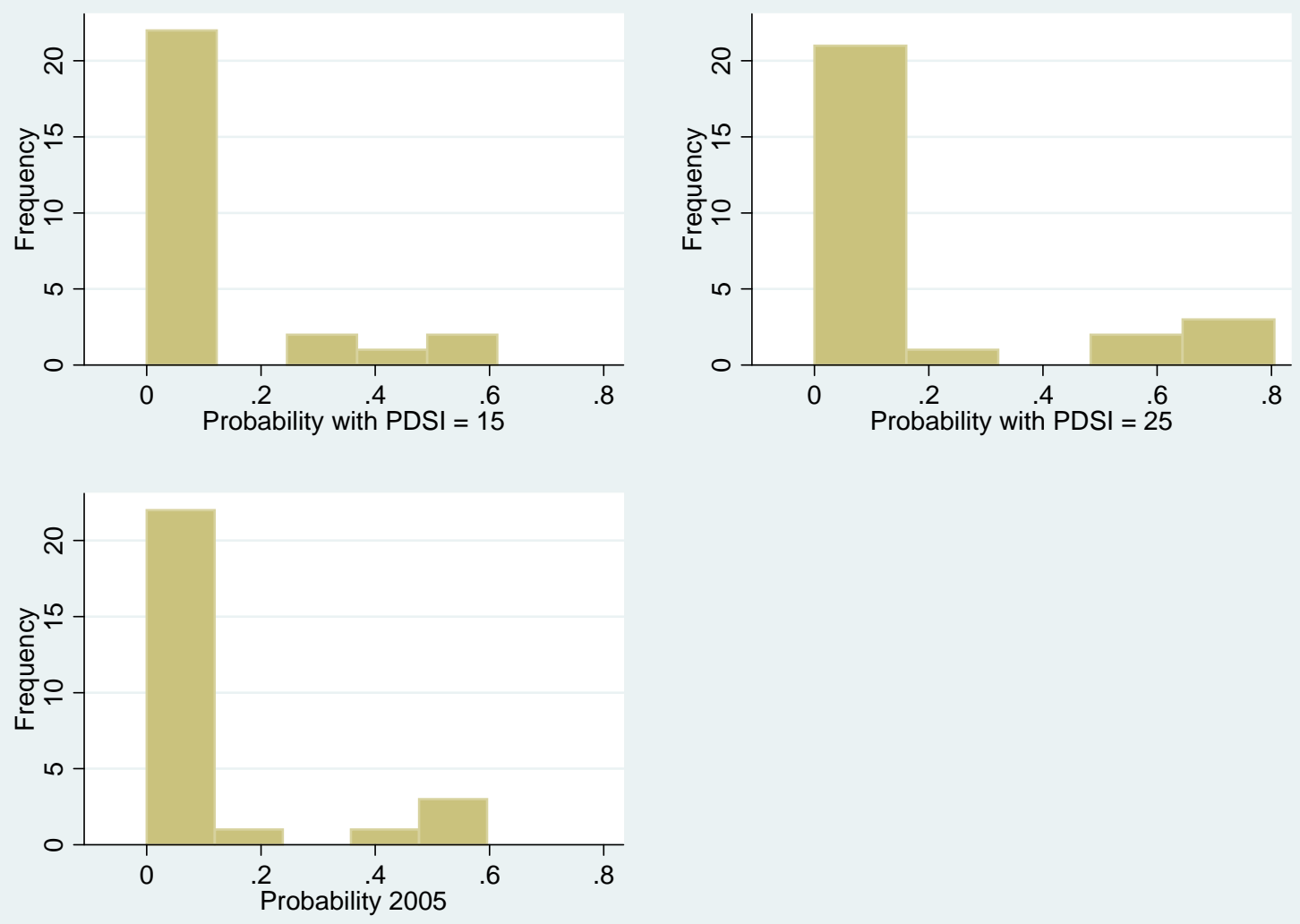
Figure 5: Country Cases
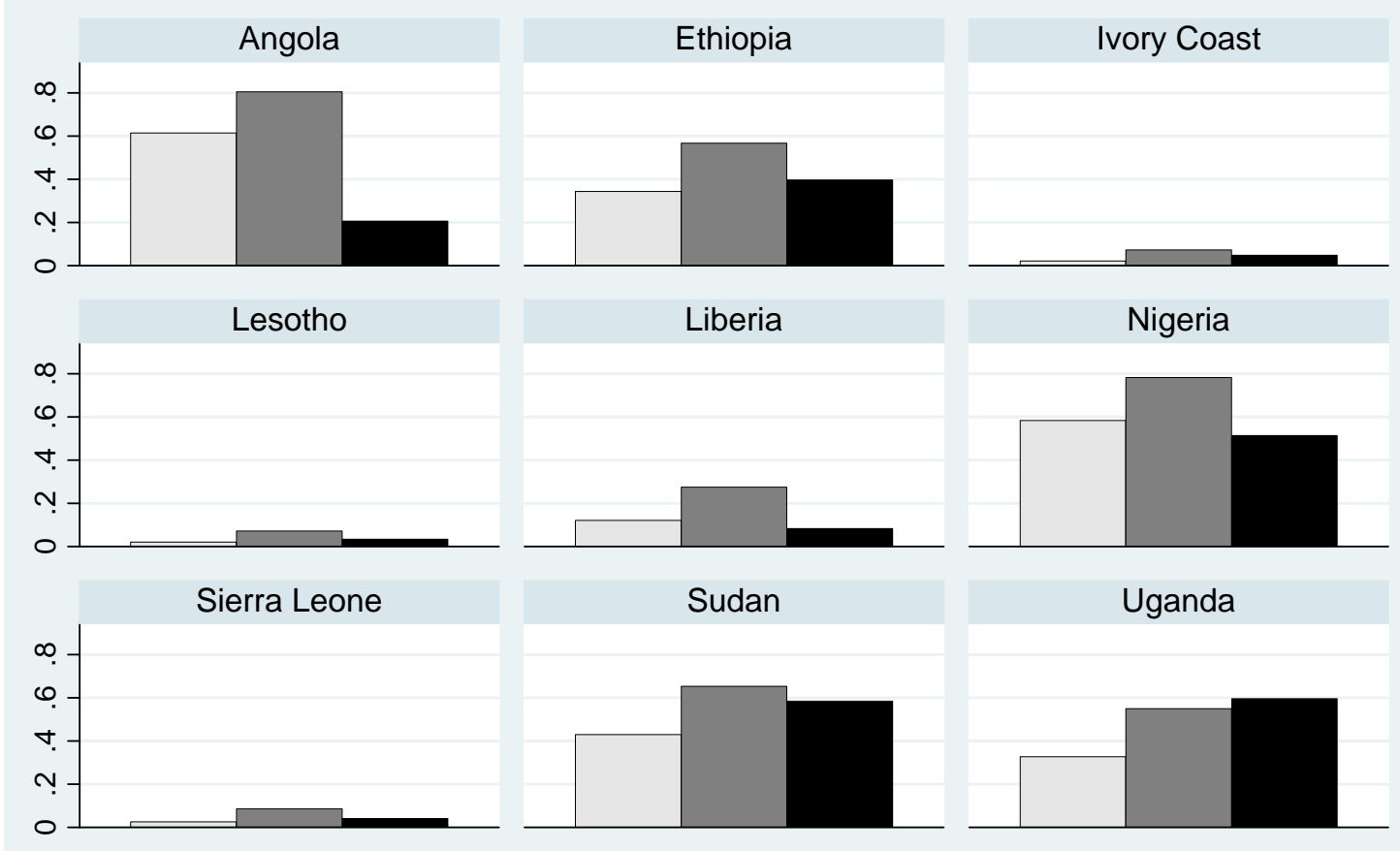

Probability with PDSI $=15 \square$ Probability with PDSI $=25$

Probability 2005 


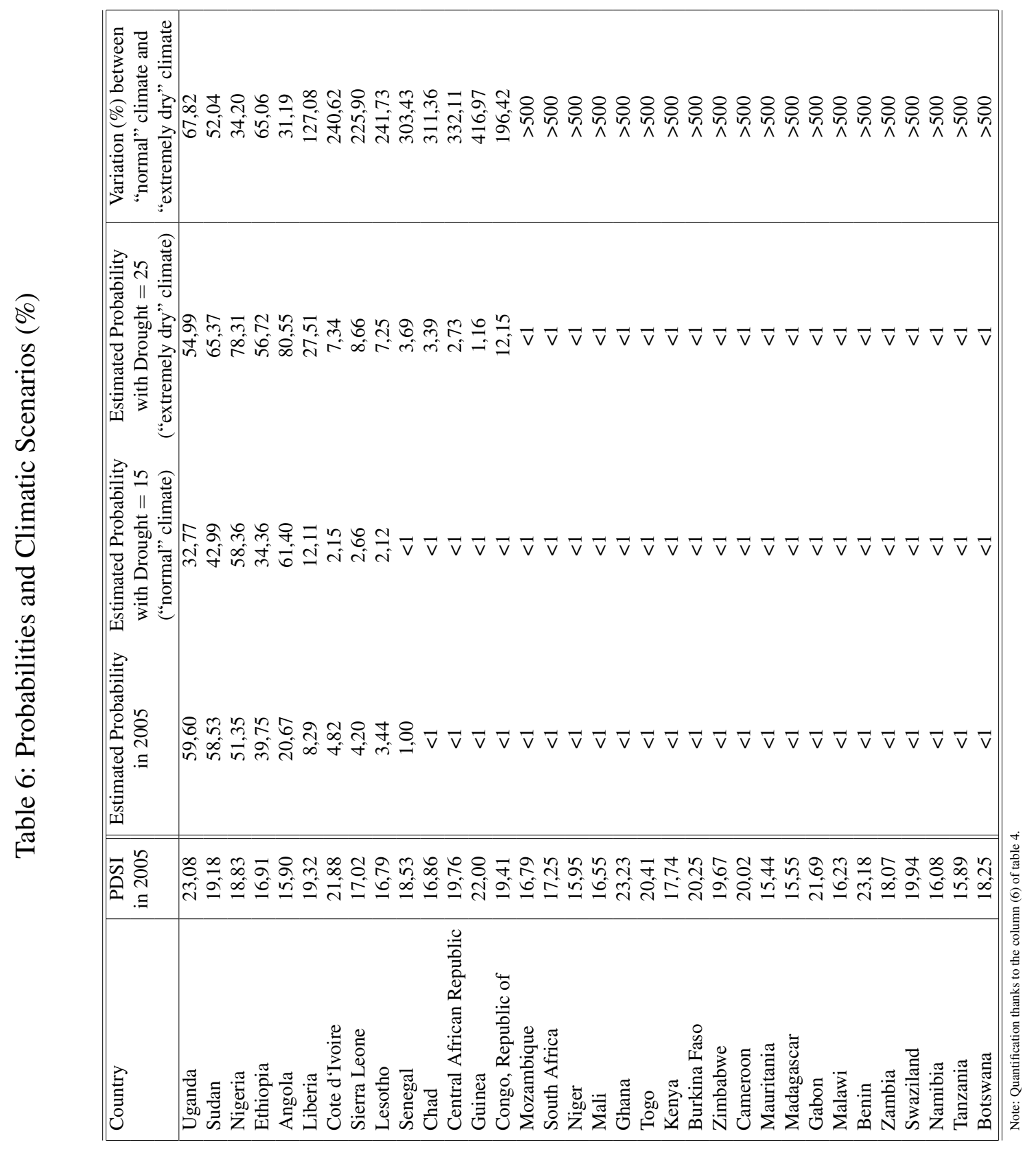




\section{Appendix B: Correlates of War Data}

Table 7: Drought and Civil War Incidence (COW)

\begin{tabular}{|c|c|c|c|c|c|}
\hline WAR (COW) & All & All & $\begin{array}{c}\text { After } \\
\text { Independence }\end{array}$ & $\begin{array}{c}\text { After } \\
\text { Independence }\end{array}$ & $\begin{array}{c}\text { After } \\
\text { Independence } \\
\text { w/o infl. obs. }\end{array}$ \\
\hline Drought(PDSI) & $\begin{array}{c}0.653 * * * \\
(0.215)\end{array}$ & $\begin{array}{c}0.346 \\
(0.215)\end{array}$ & $\begin{array}{c}1.026 * * * \\
(0.278)\end{array}$ & $\begin{array}{c}0.857 * * * \\
(0.268)\end{array}$ & $\begin{array}{c}0.415^{* * *} \\
(0.125)\end{array}$ \\
\hline $\begin{array}{l}\text { Country Fixed Effect: } \\
\text { Country Time }\end{array}$ & - & Yes & Yes & Yes & Yes \\
\hline Trends : & - & Yes & Yes & - & Yes \\
\hline Common Time Trend : & - & - & - & Yes & - \\
\hline Observations & 2,257 & 2,257 & 1,597 & 1,597 & 1,519 \\
\hline $\mathrm{R}$-squared & 0.004 & 0.376 & 0.471 & 0.387 & 0.544 \\
\hline
\end{tabular}

Figure 6: Drought Effect with Different Time Frame (COW)

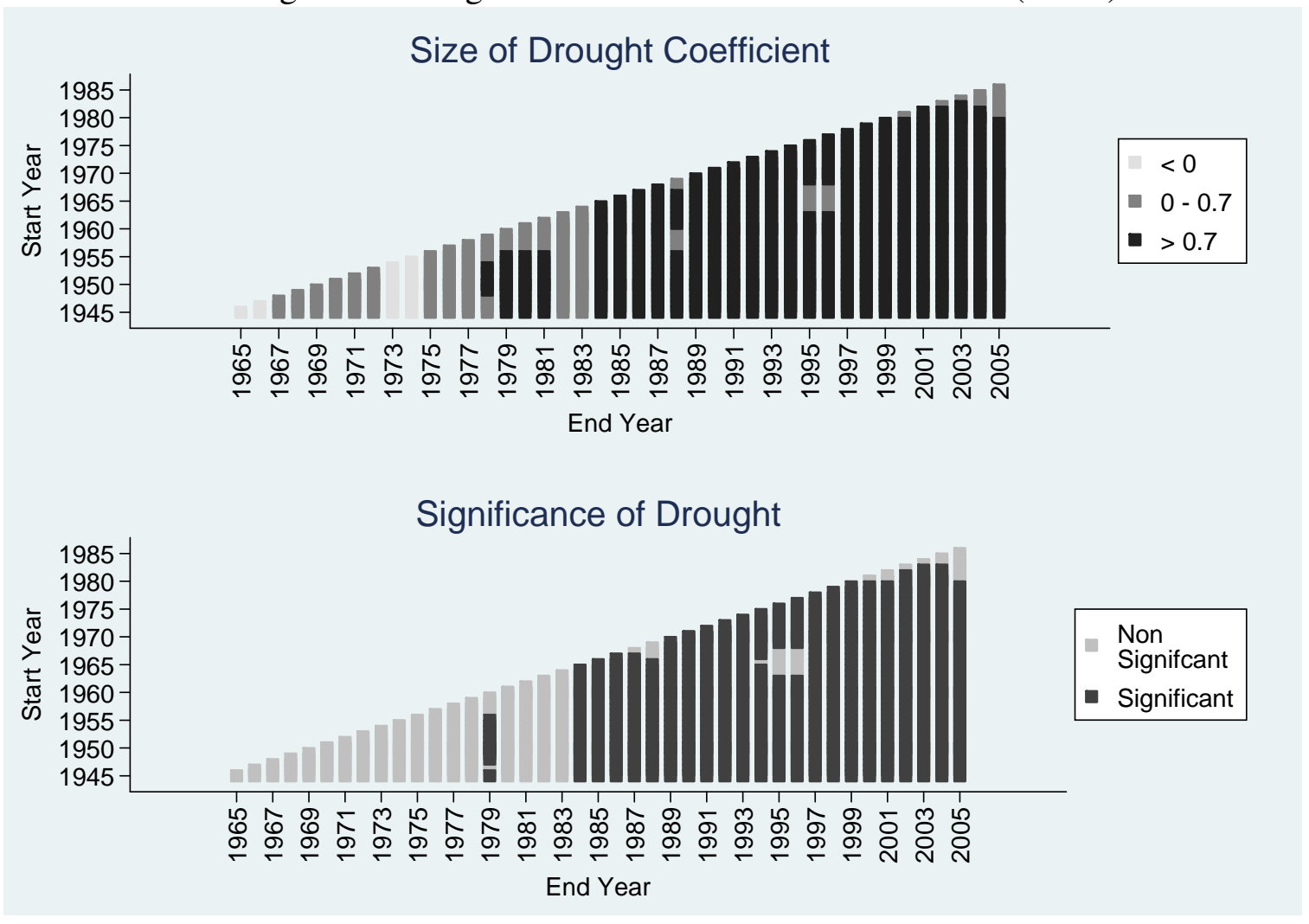




\section{References}

Bertrand, M., E. Duflo, and S. Mullainathan (2004, February). How much should we trust differences-in-differences estimates? The Quarterly Journal of Economics 119(1), 249-275.

Brückner, M. (2010, 05). Population size and civil conflict risk: Is there a causal link? Economic Journal 120(544), 535-550.

Buhaug, H. (2010). Climate not to blame for african civil wars. Proceedings of the National Academy of Sciences 107(38), 16477-16482.

Buhaug, H., H. Hegre, and H. Strand (2010). Sensitivity analysis of climate variability and civil war. Technical report, PRIO Paper. Oslo.

Burke, M., J. Dykema, D. Lobell, E. Miguel, and S. Satyanath (2009). Warming increases the risk of civil war in africa. Proceedings of the National Academy of Sciences 106(49), 20670-20674.

Burke, M., J. Dykema, D. Lobell, E. Miguel, and S. Satyanath (2010a, October). Climate and civil war: Is the relationship robust? NBER Working Papers 16440, National Bureau of Economic Research, Inc.

Burke, M., J. Dykema, D. Lobell, E. Miguel, and S. Satyanath (2010b). Climate robustly linked to african civil war. Proceedings of the National Academy of Sciences 107(51), E185.

Cameron, A. C., J. B. Gelbach, and D. L. Miller (2008, 05). Bootstrap-based improvements for inference with clustered errors. The Review of Economics and Statistics 90(3), 414-427.

Cameron, A. C. and D. L. Miller (2011). Robust Inference with Clustered Data. A. Ullah and D. E. Giles eds., Handbook of Empirical Economics and Finance, CRC Press, pp.1-28. 
Ciccone, A. (2011). Transitory economic shocks and civil conflict: A comment. Technical report, Forthcoming American Economic Journal: Applied Economics.

Collier, P. and A. Hoeffler (2004, October). Greed and grievance in civil war. Oxford Economic Papers 56(4), 563-595.

Fearon, J. D. and D. Laitin (2003). Ethnicity, insurgency, and civil war. American Political Science Review 97(14), 75-91.

Greene, W. (2002). Econometric Analysis. Prentice Hall.

Jensen, P. S. and K. S. Gleditsch (2009). Rain, growth, and civil war: The importance of location. Defence and Peace Economics 20(5), 359-372.

Landon-Lane, J., H. Rockoff, and R. H. Steckel (2009, December). Droughts, floods and financial distress in the united states. NBER Working Papers 15596, National Bureau of Economic Research, Inc.

Miguel, E. and S. Satyanath (2011). Re-examining economic shocks and civil conflict. Technical report, Forthcoming American Economic Journal: Applied Economics.

Miguel, E., S. Satyanath, and E. Sergenti (2004). Economic shocks and civil conflict: An instrumental variables approach. Journal of Political Economy 112(4), 725-53.

Palmer, W. (1965). Meteorological drought. Research Paper 45, US Dept. of Commerce.

Stephan, F. (2009). Forecast: The Surprising-and Immediate-Consequences of Climate Change.

Wooldridge, J. (2002). Econometric Analysis of Cross Section and Panel Data. MIT Press, Cambridge, MA. 